\title{
Impact of different mechanical ventilation strategies for night purging on indoor air quality in public buildings
}

\author{
Sami Lestinen ${ }^{1 *}$, Simo Kilpeläinen ${ }^{1}$, Risto Kosonen ${ }^{1,2}$, and Juha Jokisalo ${ }^{1}$ \\ ${ }^{1}$ Aalto University School of Engineering, Department of Mechanical Engineering, Sähkömiehentie 4, 02150 Espoo, Finland \\ ${ }^{2}$ Nanjing Tech University, College of Urban Construction, Nanjing, 210009 China
}

\begin{abstract}
Night-time ventilation has been used in non-residential buildings to enhance indoor air quality before occupied periods. However, many hypotheses exist on how this ventilation should be used. A typical choice has been to shut down the ventilation after occupancy and restart the ventilation again 2 hours before occupancy. Another option has been to ventilate the buildings continuously. In this study, the shut-down, continuous, and intermittent ventilation strategies were compared by evaluating indoor air quality. The daily occupied-hour ventilation was kept as usual. Each test case lasted for 2 weeks. Indoor air quality was assessed by measuring TVOC concentrations. Also, the thermal conditions, carbon dioxide, and pressure differences over the building envelope and over the air distribution devices were measured. The results show that the averaged TVOC concentrations were at the same level in the mornings with all those ventilation strategies. The evening concentrations reached a minimum level after a 2-hour purging period. TVOC concentrations were higher during the day than at night. This reveals that space usage had the largest effect on TVOC concentrations. The results indicate that a 2-hour purging is enough to cleanse indoor air before occupancy, and therefore the continuous night-time ventilation is not necessary.
\end{abstract}

\section{Introduction}

Ventilation plays a central role while improving wellbeing indoors [1]-[3]. This is important in schools and kindergartens because indoor air quality has effects on learning [4]-[7]. However, concerns about indoor air quality may have led to additional ventilation use that increases energy consumption. Consequently, this study provides insights into the ventilation strategies that are used for unoccupied periods in non-residential buildings. The European standard 15251:2007 recommends using pre-started or continuous minimum ventilation during the unoccupied hours to guarantee good indoor air quality at the beginning of the occupied periods [8]. A typical choice has been to turn off the ventilation after occupancy and restart the ventilation 2hours before occupancy. Another strategy has been to ventilate continuously 24 hours per day by using demand-controlled ventilation. A third option could be to ventilate intermittently during those unoccupied hours by operating the ventilation couple of hour intervals.

Poor ventilation is a universal challenge. Earlier studies have shown that the low ventilation rates are common in schools worsening the health symptoms of children and adults [3], [6], [9], [10]. Although many health-based ventilation guidelines and standards have been published [8], [11], [12], the effects of unoccupied ventilation strategies on organic pollutants are rather seldom studied. Earlier studies indicate that night purging has been mainly used for improving indoor thermal conditions [13]-[18]. In schools, a common purging strategy has been simply to open windows or doors [19]-[21]. Chao and $\mathrm{Hu}$ [22] concluded that the occupants in a lecture theatre may be exposed to indoor air pollutants because unoccupied contaminants can accumulate at a higher level if the ventilation is off during the unoccupied hours. In a subsequent study, Montgomery et al. [23] stated that the high TVOC concentrations in the morning can be a consequence of off-gassing of building materials while the ventilation is not used during the unoccupancy at night. Hunt and Kaye [24] proposed that the necessary flushing rate of contaminants is basically a function of room volume, air distribution, and buoyancy sources.

It follows that many hypotheses exist on how indoor spaces should be ventilated during unoccupied hours. For instance, one may think that by turning off the mechanical ventilation system, the concentrations of harmful substances may increase in indoor air. Another concern has been the indoor humidity conditions if the ventilation is off. However, if the ventilation system is operating continuously, the energy consumption may increase remarkably.

Nowadays, $\mathrm{CO}_{2}$ is a typical monitoring proxy for air quality. Also, many material and biological pollutants can occur from indoor or outdoor sources. It is known that the organic and microbiologic compounds are likely the causative agents on health, but it is difficult to show which compounds are the important ones [25]. VOC concentration levels have been assessed by monitoring a total amount of volatile organic compounds (TVOC)

\footnotetext{
* Corresponding author: sami.lestinen@aalto.fi
} 
that may provide a general trend of VOC levels in indoor air e.g. by approximating a toluene equivalent spectrum. However, individual VOCs are not able to be identified with this method. Regardless of that, the TVOC concentration can be a good general measure of organic pollutants in indoor air [26]-[28].

In this study, the pre-started (test case 1), the continuous (test case 2), and the intermittent (test case 3) ventilation strategies for unoccupied hours were compared by measuring indoor air quality. The spaces were ventilated normally during occupied hours. The motivation of the study was that unnecessary night ventilation increases energy consumption, and therefore, the ventilation is desired to be used only as much as reasonable. The objective of the study was to provide more information for building owners about the night-ventilation strategies in non-residential buildings. The novelty of the study lies in investigations of those rarely studied night-purging strategies. The novelty comes also from the effects of strategies on TVOCconcentrations in the morning periods just before the occupied periods. Further target was measuring the indoor air quality and thermal conditions in nonresidential buildings that have not the reported complaints on indoor air quality.

\section{Methods}

The measurements were carried out in two schools and two kindergartens (Figure 1). The chosen indoor environments were a classroom in primary school that was measured in winter (Figure 1a), a playroom in kindergarten (Figure 1b) measured in winter, a playroom in kindergarten measured in autumn (Figure $1 \mathrm{c}$ ), and a classroom in secondary school measured in autumn (Figure 1d). The primary and secondary schools had a variable air volume system (VAV) and both the kindergartens had a constant air volume system (CAV).
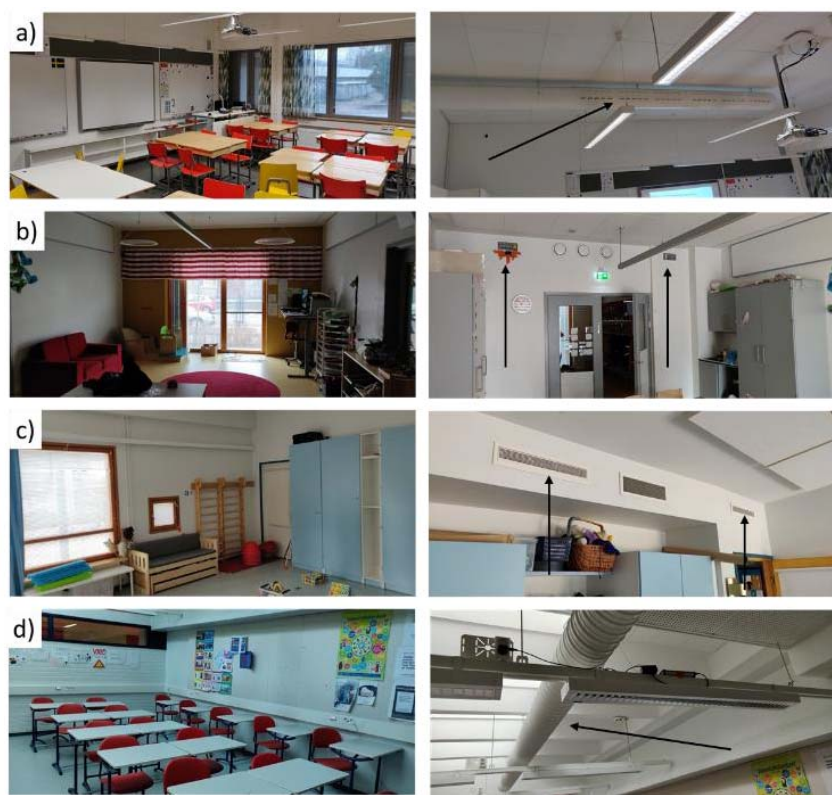

Figure 1. Measured non-residential rooms: a) the classroom in primary school with a duct air distribution system (right), b) the playroom in kindergarten 1 with a corridor wall air distribution, c) the playroom in kindergarten 2 with a corridor wall air distribution and d) the classroom in secondary school with a duct air distribution system.

\subsection{Classroom in primary school}

The classroom $\left(40 \mathrm{~m}^{2}\right)$ had a nozzle duct VAV air distribution system at the ceiling zone (Figure 1a). The exhaust grille was at the corridor wall. Supply air temperature $\left(\mathrm{T}_{\mathrm{in}}\right)$ was adjusted by outdoor air temperature $\left(\mathrm{T}_{\text {out }}\right)$ so that $\mathrm{T}_{\text {in }}$ was from $17^{\circ} \mathrm{C}$ to $15^{\circ} \mathrm{C}$, while $\mathrm{T}_{\text {out }}$ was from $12^{\circ} \mathrm{C}$ to $16^{\circ} \mathrm{C}$, respectively. The indoor air temperature target was $21^{\circ} \mathrm{C}$ and the carbon dioxide concentration limits were $700 \mathrm{ppm}$ and $900 \mathrm{ppm}$ where the airflow rate was adjusted from minimum to maximum airflow. When the space was empty, the ventilation was operating at $50 \%$, corresponding approximately to $70 \%$ of the maximum air volume flow of $120 \mathrm{~L} / \mathrm{s}$ that was designed for 20 individuals. The test cases are shown in Table 1.

Table 1. Test cases of the classroom in primary school.

\begin{tabular}{|l|l|l|l|}
\hline \multicolumn{4}{|l|}{ Primary school } \\
\hline $01-03 / 2020$ & \multicolumn{1}{c|}{ Weekdays } & \multicolumn{1}{c|}{ Weekend } \\
\hline T1 & Pre-start & $\begin{array}{l}\text { mon 04-18+ tue- } \\
\text { fri 05-18 }\end{array}$ & $\begin{array}{l}\text { sat-sun 1h per } \\
\text { day }\end{array}$ \\
\hline T2 & Continuous & $00-24$ & $00-24$ \\
\hline T3 & Intermittent & $\begin{array}{l}\text { T1 } \\
+20-22,00-02\end{array}$ & $02-05$ \\
& & $+10-13+18-21$ \\
\hline \multicolumn{4}{|l}{ Relative ventilation airflow: T2/T1=2.1, T3/T1=1.3 } \\
\hline
\end{tabular}

\subsection{Playroom in kindergarten 1}

The playroom $\left(37 \mathrm{~m}^{2}\right)$ had a corridor bulkhead CAV air distribution system (Figure 1b). The supply air temperature setpoints were from $22^{\circ} \mathrm{C}$ to $17^{\circ} \mathrm{C}$ when the exhaust air temperature was from $20^{\circ} \mathrm{C}$ to $25^{\circ} \mathrm{C}$, respectively. The operation of air handling units was controlled by a time program. The units in the stairwell and the elevator shaft operated 24 hours a day. The heating kitchen followed the normal schedule. The building automation system had monitoring of TVOC, air temperature, and relative humidity. The designed supply airflow rate was $110 \mathrm{~L} / \mathrm{s}$ for the $10-20$ individuals. The test cases are shown in Table 2.

Table 2. Test cases of the playroom in kindergarten 1.

\begin{tabular}{|l|l|l|l|}
\hline \multicolumn{4}{|l|}{ Kindergarten 1} \\
\hline $01-02 / 2020$ & \multicolumn{1}{|c|}{ Weekdays } & \multicolumn{1}{|c|}{ Weekend } \\
\hline T1 & Pre-start & $03: 00-17: 00$ & $04: 00-17: 00$ \\
\hline T2 & Continuous & $00-24$ & $00-24$ \\
\hline T3 & Intermittent & $04-20+22-01$ & $00-04+08-12+$ \\
& & $16-20$ \\
\hline
\end{tabular}




\subsection{Playroom in kindergarten 2}

The playroom $\left(\sim 30 \mathrm{~m}^{2}\right)$ had a corridor bulkhead CAV air distribution system (Figure 1c) with cascade control of the supply air temperature based on the exhaust air temperature. The air handling units in the other service areas had a shorter operating time than in the playroom. The designed supply airflow rate was $105 \mathrm{~L} / \mathrm{s}$ for 5-15 individuals. The test cases are shown in Table 3.

Table 3. Test cases of the playroom in kindergarten 2.

\begin{tabular}{|c|c|c|c|}
\hline \multicolumn{4}{|c|}{ Kindergarten 2} \\
\hline \multicolumn{2}{|c|}{$08-09 / 2020$} & Weekdays & Weekend \\
\hline $\mathrm{T} 1$ & Pre-start & $\begin{array}{l}\text { mon } \\
04: 30-21: 00 \\
\text { tue-fri } \\
05: 30-21: 00\end{array}$ & 1h per day \\
\hline $\mathrm{T} 2$ & Continuous & $00-24$ & $00-24$ \\
\hline $\mathrm{T} 3$ & Intermittent & $\begin{array}{l}\text { T1 } \\
+01-03\end{array}$ & $\begin{array}{l}02-05 \\
+10-13+18-21\end{array}$ \\
\hline
\end{tabular}

\subsection{Classroom in secondary school}

The classroom $\left(42 \mathrm{~m}^{2}\right)$ had a perforated duct diffuser VAV air distribution system from where the supply air was distributed 180 degrees upwards (Figure 1d). The exhaust air grille was in the middle of the room on the corridor wall. The ventilation system operated with temperature and carbon dioxide control with the minimum limit value of $21^{\circ} \mathrm{C}$ and the maximum limit value of $650 \mathrm{ppm}$, after which the ventilation increased gradually $(20 \% \ldots 100 \%)$ up to the maximum level of $6 \mathrm{~L} / \mathrm{s}$ per person for 25 individuals. The skylight raised the room height. The test cases are shown in Table 4.

Table 4. Test cases of the classroom in secondary school.

\begin{tabular}{|l|l|l|l|}
\hline \multicolumn{3}{|l|}{ Secondary school } \\
\hline $08-10 / 2020$ & \multicolumn{1}{|c|}{ Weekdays } & Weekend \\
\hline T1 & Pre-start & $\begin{array}{l}\text { mon 05-17 } \\
\text { tue-fri 06-17 }\end{array}$ & - \\
\hline T2 & Continuous & $00-24$ & $00-24$ \\
\hline T3 & Intermittent & - & - \\
\hline \multicolumn{4}{|l}{ Relative ventilation airflow: T2/T1=1.7 } \\
\hline
\end{tabular}

\subsection{Measuring instruments}

The measuring instruments are shown in Table 5. The pressure difference in the building envelope was measured with a Sensirion manometer, which was sending the data to the cloud service at a recording interval of 30 minutes. A performance of supply air devices was measured using either the Sensirion manometer or the Swema 3000 manometer, in which a logging interval was $5 \mathrm{~min}$. The thermal conditions and $\mathrm{CO}_{2}$ concentrations were obtained using Tinytag loggers at the height of $1.1 \mathrm{~m}$, where a recording interval of 5 min was used. TVOC measurement was performed by the metal oxide semiconductor method using a Nuvap IEQ monitor located mainly on a shelf. A sampling was every 20 minutes.

Table 5. The measuring instruments.

\begin{tabular}{|c|c|c|}
\hline Type & $\begin{array}{c}\text { Measured } \\
\text { quantity }\end{array}$ & Accuracy \\
\hline Swema 3000 & $\begin{array}{c}\text { pressure } \\
\text { difference }\end{array}$ & $\pm(0.3 \% \pm 0.3 \mathrm{~Pa})$ \\
\hline $\begin{array}{c}\text { Sensirion } \\
\text { SDP816-125 Pa }\end{array}$ & $\begin{array}{c}\text { pressure } \\
\text { difference }\end{array}$ & $\pm(3 \% \pm 0.08 \mathrm{~Pa})$ \\
\hline $\begin{array}{c}\text { Tinytag plus } 2 \\
\text { TGP-4500 }\end{array}$ & $\begin{array}{c}\text { temperature } \\
\text { and humidity }\end{array}$ & $\pm 0.5{ }^{\circ} \mathrm{C}$ \\
$\pm 3.0 \% \mathrm{RH}$ \\
\hline Tinytag & CO 2 & $\pm(3 \% \pm 50 \mathrm{ppm})$ \\
TGE-0011 & & \\
\hline Nuvap IEQ \\
monitor
\end{tabular}

\section{Results}

Figure 2 shows the temporal variation of TVOC concentration, air distribution performance, and pressure difference of building envelope during the weekday morning in the primary school classroom. The results show that the measured pressure difference over the building envelope was reasonable. The measured difference was below $10 \mathrm{~Pa}$ in the studied cases and typically below $5 \mathrm{~Pa}$.

In test case 1 , the pre-started ventilation strategy decreased the TVOC concentration near the minimum level approximately two hours after the start of ventilation. In test case 2 , continuous ventilation kept the TVOC concentration to a minimum at night. However, the TVOC concentration increased in the morning rather similarly than the pre-started ventilation, although the concentration with the continuous strategy was slightly lower at 7:00. The morning cleaning was at 7:00-8:00 and the lessons began at 8:00-8:30. In test case 3 (intermittent), start-up and shut-off ventilation clearly affected changes in the TVOC concentration at night, such that the TVOC concentration decreased after the start-up and increased after the shut-off. This can probably be explained by material emissions or differences in the schedules of ventilation zones, allowing contaminants to enter the room as internal flows. This observation was also often observed in other measured buildings.

In Figure 2, the continuous ventilation caused a slightly lower level of TVOC-concentration in the morning lessons than those other studied strategies. However, this difference was within the measurement uncertainty. These types of differences were rather usual and found to be a case-dependent issue varying between test periods and buildings. Consequently, systematic similarities were not found in the measured test periods. However, the night-time TVOC-concentrations were 
often at a higher level with intermittent ventilation than with those other studied strategies, most probably due to different operation schedules of air handling units, which are important to be synchronized in the building automation.

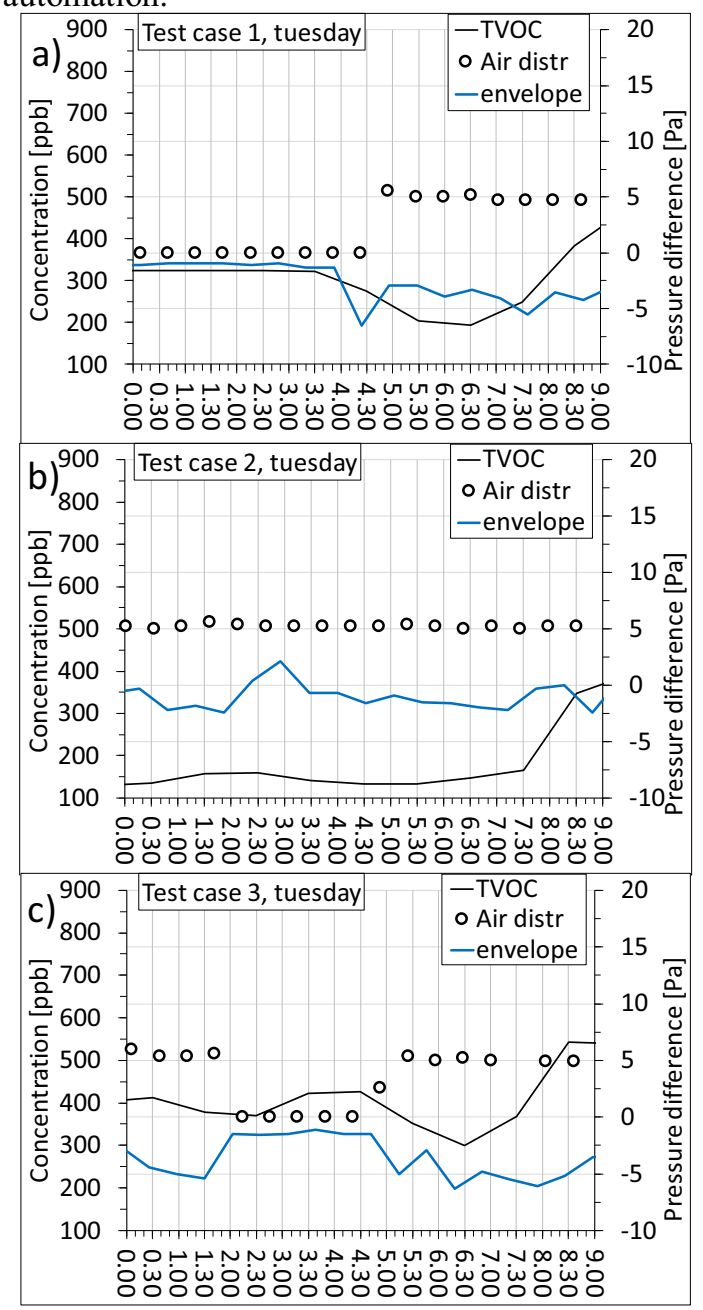

Figure 2. TVOC-concentration, and pressure difference in the air distribution device and over the building envelope. The primary school classroom in a weekday morning: a) the pre-started ventilation, b) the continuous ventilation and c) the intermittent ventilation.

It follows that daytime space usage seemed to have the greatest impact on daily indoor air quality. The results show that the TVOC concentration increased mainly due to daily space use because the changes in TVOC-concentrations correlate with the corresponding $\mathrm{CO} 2$-concentration changes originating from people. This can be seen clearly in Figure 3, where the carbondioxide peaks are rather near the local TVOC maximums. This may complement earlier knowledge and justify common practices that carbon-dioxide monitoring is used also in estimating the bio emissions from individuals and space usage. In Figure 3, the carbon dioxide levels were generally reasonable, although natural variation exists between the test periods. In test case 1 , the total amount of carbondioxide was greater on this morning lessons than in those other studied test cases. For this reason, the TVOC-level was obviously slightly higher than with the continuous test case 2, although the TVOC minimum level was slightly smaller with continuous ventilation than with pre-started ventilation at 7:00. Most probably, the morning lessons lasted longer on this day, because the $\mathrm{CO} 2$ concentration was at a similar level than in those other test cases, indicating that the number of people was of the same order of magnitude.

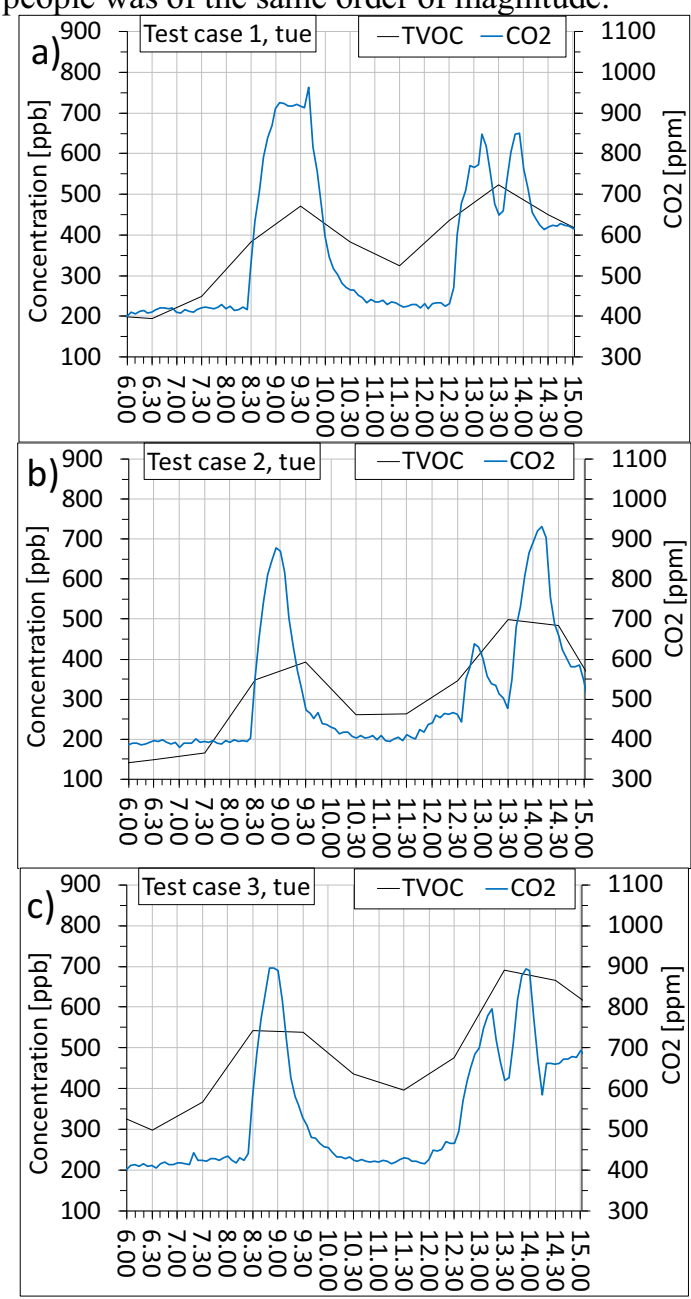

Figure 3. TVOC and carbon dioxide concentrations. The primary school classroom in a weekday: a) the pre-started ventilation, b) the continuous ventilation and c) the intermittent ventilation.

Figure 4 and Figure 5 show the air temperature and relative humidity conditions in the primary school classroom in the winter conditions, respectively. The results indicate that the air temperature and relative humidity were stable at night and started to increase at the beginning of lessons due to heat and humidity originating from people. Those results follow rather closely a general trend of the measured buildings, such that the indoor air temperature and the relative humidity were stable during the morning periods at 00:00-6:00. Therefore, these values most probably did not affect the TVOC levels at night. This is because the TVOC gases may usually come from the material emissions or from the other spaces, and therefore, the indoor temperature and humidity conditions can have a noticeable effect on the results. 


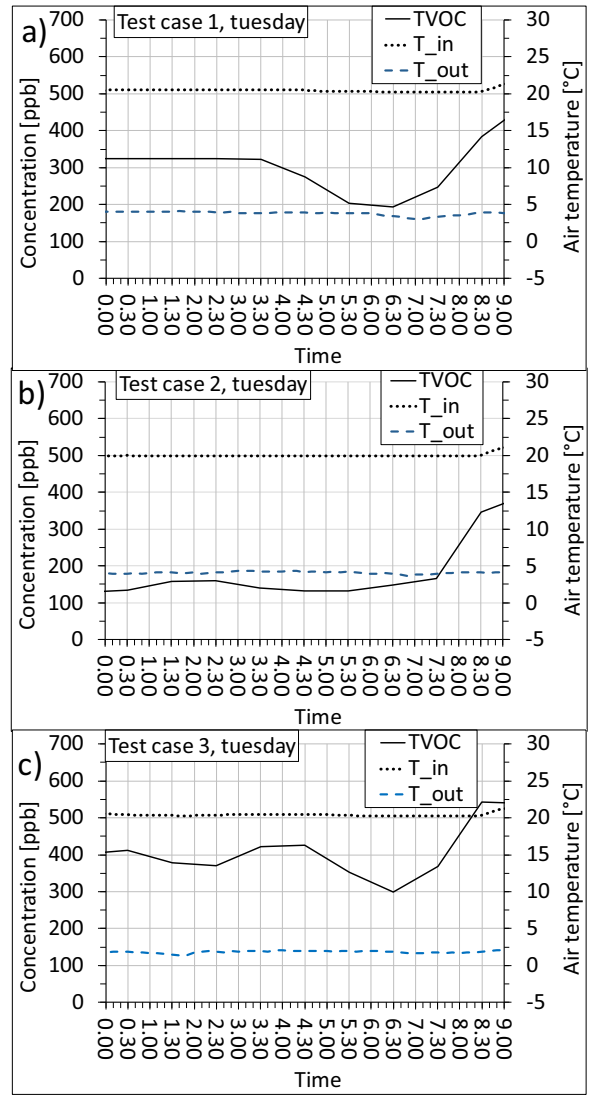

Figure 4. TVOC concentration and air temperature indoors and outdoors. The primary school classroom in a weekday morning: a) the pre-started ventilation, b) the continuous ventilation and c) the intermittent ventilation.

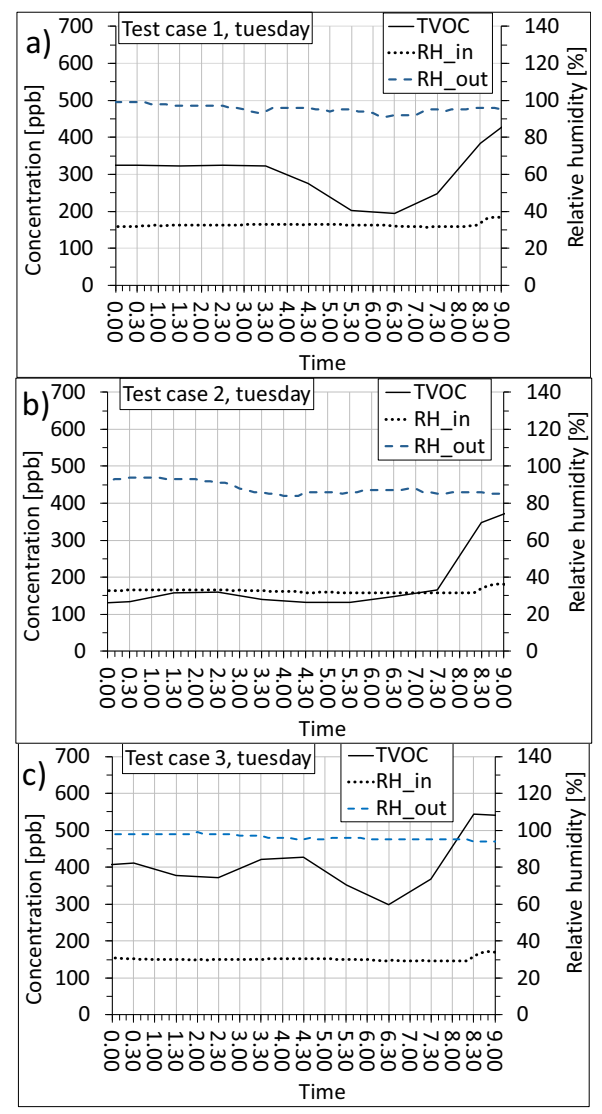

Figure 5. TVOC concentration, and relative humidity indoors and outdoors. The primary school classroom in a weekday morning: a) the pre-started ventilation, b) the continuous ventilation and c) the intermittent ventilation.

Figure 6 shows the average weekday morning TVOC concentration with the pre-started, continuous, and intermittent ventilation strategy. The results propose that the operation strategy of night-time ventilation is not relevant for the morning indoor air quality if the ventilation will be started 2 hours before the space use. At night, intermittent ventilation strategy produced the highest TVOC concentrations, which decreased in the mornings to the same level as in other test cases. Higher TVOC concentrations in the intermittent night ventilation were likely to be due to pressure differences of the service areas of different air-handling units because contaminants can move from one premise to another. With the continuous use of ventilation, TVOC concentrations were the lowest level at night, but the concentration increased in the mornings, rather similarly than in the other test cases, with the onset of space use.

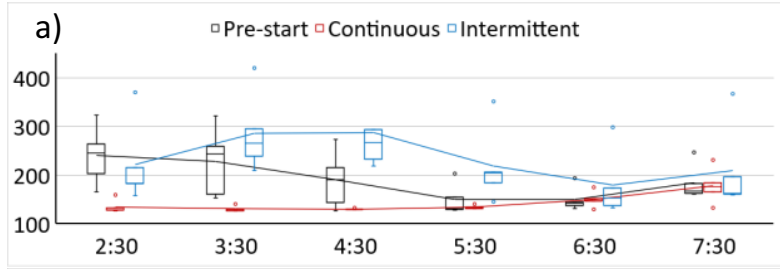

b) $\quad$ Pre-start $\square$ Continuous $\square$ Intermittent

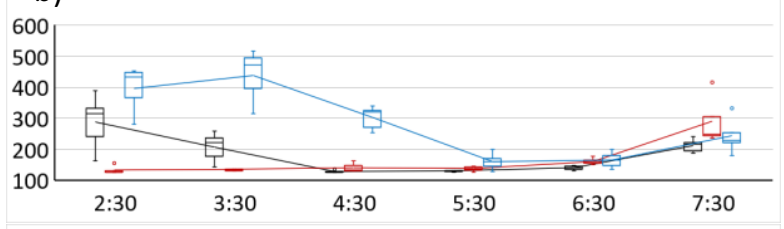

C) $\quad$ Pre-start $\square$ Continuous $\square$ Intermittent

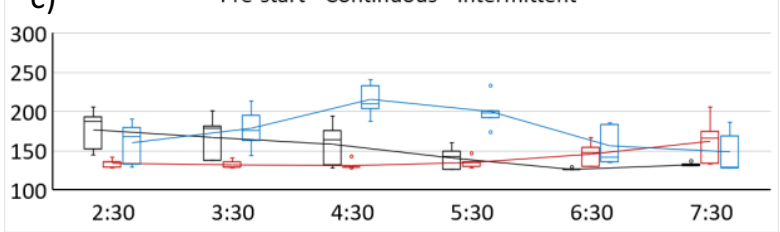

d) $\quad \square$ Pre-start $\square$ Continuous

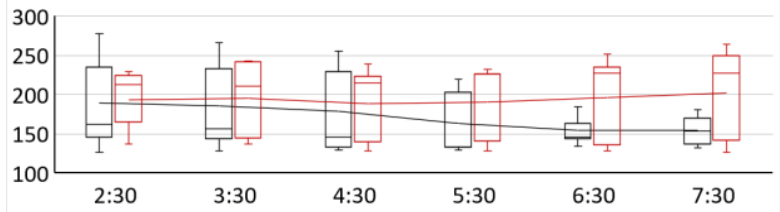

Figure 6. TVOC concentration [ppb] in the weekday mornings: a) the classroom in primary school, b) the playroom in kindergarten $1, \mathrm{c}$ ) the playroom in kindergarten 2 and d) the classroom in secondary school (intermittent test case not available). The line follows the average concentration. The vertical axis is concentration and the horizontal axis is time.

Table 6 shows the averaged TVOC concentrations in the measured spaces with each test case during the selected measuring periods. The results show a reasonable variation of concentration levels in each indoor environment. However, the intermittent ventilation strategy provided higher TVOC concentration and deviation during the one-week period than the other strategies studied. This difference was not 
so clear in the morning periods before occupancy (weekday at 6:00-8:00). Generally, the systematic and reliable differences between the test cases were not found and the average TVOC concentration varied casedependently within the measurement uncertainty. However, the standard deviation was often smallest with the pre-started ventilation strategy.

Table 6. TVOC concentrations. AVG is the arithmetic average, $\mathrm{SD}$ is the standard deviation. $\mathrm{T} 1$ is the pre-started ventilation, T2 is the continuous ventilation and T3 is the intermittent ventilation.

\begin{tabular}{|c|c|c|c|c|c|c|}
\hline TVOC & \multicolumn{2}{|c|}{ 1 week } & weekday 8-16 & weekday 6-8 \\
\hline [ppb] & AVG & SD & AVG & SD & AVG & SD \\
\hline \multicolumn{7}{|c|}{ Classroom in primary school (Figure 1a) } \\
\hline T1 & 238 & 85 & 330 & 96 & 167 & 31 \\
\hline T2 & 210 & 87 & 325 & 23 & 165 & 26 \\
\hline T3 & 287 & 129 & 398 & 154 & 195 & 79 \\
\hline \multicolumn{7}{|c|}{ Playroom in kindergarten 1 (Figure 1b) } \\
\hline T1 & 223 & 75 & 222 & 14 & 177 & 12 \\
\hline T2 & 191 & 95 & 341 & 40 & 226 & 42 \\
\hline T3 & 276 & 112 & 278 & 94 & 205 & 39 \\
\hline \multicolumn{7}{|c|}{ Playroom in kindergarten 2 (Figure 1c) } \\
\hline T1 & 186 & 62 & 263 & 15 & 130 & 2,1 \\
\hline T2 & 180 & 87 & 317 & 70 & 154 & 23 \\
\hline T3 & 212 & 92 & 311 & 53 & 153 & 27 \\
\hline \multicolumn{7}{|c|}{ Classroom in secondary school (Figure 1d) } \\
\hline T1 & 195 & 46 & 202 & 23 & 155 & 19 \\
\hline T2 & 194 & 79 & 272 & 88 & 199 & 61 \\
\hline T3 & - & - & - & - & - & - \\
\hline
\end{tabular}

\section{Discussion}

The results indicate that the main source of TVOC was daily space use and the night-ventilation had minor effects on indoor climate conditions. This was a rather expected result because the 2-hour ventilation criterion is a well-known practice. However, this criterion may depend on a pollution load of spaces and outdoor levels, but usually, the standard recommendations are a good goal, although the higher ventilation rates would reduce the health outcomes [8], [29]-[31]. Furthermore, the air distribution system itself may have considerable effects on indoor air quality, thermal discomfort, and energy efficiency [32]-[34]. In school classrooms, the human bio emissions are often dominating whereas the additional pollutants may come from outdoors or building materials and learning activities [35].

TVOC concentration was at the normal level in the mornings with all those studied night purging strategies. However, TVOC concentration depends largely on individual VOC-concentrations. Therefore, it must be kept in mind that the measured TVOC is only a trend of volatile organic compounds and not an exact value that justifies the classification of an indoor environment. However, it can be a good general measure of organic pollutants in indoor air.

The initial hypotheses included the question of whether shutting down ventilation increases concentrations of harmful substances indoors or not. The results indicate that nominal ventilation for a couple of hours before the occupancy time is well enough to decrease concentration to their minimum level. Therefore, continuous ventilation is not necessary. However, it is better to start ventilation too early than too late and change the filters of the air-handling units according to recommendations to guarantee good indoor air quality for occupants. The second hypothesis inquired about the humidity levels indoors. The results show that the relative humidity levels were reasonable and stable before the occupied periods in those studied cases.

Throughout the weekly measurement period, the highest average TVOC concentration was by using intermittent use of ventilation. The likely explanation is the intermittent ventilation intervals, which cause pressure differences as well as flows between different ventilation zones, and possibly bring contaminants in from other spaces.

Based on everyday observations, the effect of ventilation and human activities was clearly noticeable, so human activities are likely to have a significant effect on the TVOC concentration in indoor environments. Also, the importance of time control synchronization of air-handling units is emphasized when looking at the room air quality results.

Carbon dioxide concentrations and thermal conditions were at normal levels and no high concentrations were observed.

\section{Conclusions}

The results show that the average TVOC concentration on weekday mornings was at the same level for all the studied night-ventilation strategies.

The results indicate that a 2-hour criterion for prestarting the ventilation is sufficient, and therefore, continuous night ventilation is not necessary.

The TVOC concentration was clearly higher during the day than at night. This indicates that space usage will have more significant effects on daily indoor TVOC concentrations than the night-time ventilation strategies.

The authors acknowledge the Finnish Work Environment Fund, the Aalto University Campus \& Real Estate (ACRE), the Senate Properties and the cities of Helsinki, Espoo and Vantaa, for the financial support.

\section{References}

[1] O. A. Seppänen, W. J. Fisk, and M. J. Mendell, "Association of ventilation rates and $\mathrm{CO} 2$ concentrations with health and other responses in commercial and institutional buildings," Indoor air, 9(4), 226-252, 1999.

[2] J. Sundell, H. Levin, W. W. Nazaroff, W. S. Cain, W. J. Fisk, D. T. Grimsrud, ... and J. M. Samet, "Ventilation rates and health: multidisciplinary review of the scientific literature," Indoor air, 21(3), 191-204, 2011.

[3] P. Wargocki, J. Sundell, W. Bischof, G. Brundrett, P.O. Fanger, F. Gyntelberg, S.O. 
Hanssen, P. Harrison, A. Pickering and O. Seppänen, "Ventilation and health in nonindustrial indoor environments: report from a European multidisciplinary scientific consensus meeting (EUROVEN)." Indoor Air, vol. 12, pp. 113-128, 2002.

[4] U. Haverinen-Shaughnessy, R. J. Shaughnessy, E. C. Cole, O. Toyinbo, and D. J.

Moschandreas, "An assessment of indoor environmental quality in schools and its association with health and performance", Building and Environment, 93, 35-40, 2015.

[5] P. Wargocki, and D. P. Wyon, "The effects of outdoor air supply rate and supply air filter condition in classrooms on the performance of schoolwork by children (RP-1257)," HVAC\&R Research, 13(2), 165-191, 2007.

[6] J. M. Daisey, W. J. Angell, and M. G. Apte, "Indoor air quality, ventilation and health symptoms in schools: an analysis of existing information," Indoor air, 13(1), 53-64, 2003.

[7] Z. Bakó-Biró, D.J. Clements-Croome, N. Kochhar, H.B. Awbi and M.J. Williams, "Ventilation rates in schools and pupils' performance," Build.Environ., vol. 48, pp. 215223, 2012.

[8] CEN, "European Standard EN 15251:2007 Indoor environmental input parameters for design and assessment of energy performance of buildings addressing indoor air quality, thermal environment, lighting and acoustics," Brussels, Belgium, 2007.

[9] M.J. Mendell and G.A. Heath, "Do indoor pollutants and thermal conditions in schools influence student performance? A critical review of the literature," Indoor Air, vol. 15, pp. 27-52, 2005.

[10] L. Chatzidiakou, D. Mumovic and A.J. Summerfield, "What do we know about indoor air quality in school classrooms? A critical review of the literature," Intelligent Buildings International, vol. 4, pp. 228-259, 2012.

[11] O. Seppänen, N. Brelih, G. Goeders and A. Litiu, "Existing buildings, building codes, ventilation standards and ventilation in Europe," Final HEALTHVENT WP5 Report, 2012.

[12] P. Carrer, E. de Oliveira Fernandes, H. Santos, O. Hänninen, S. Kephalopoulos and P. Wargocki, "On the development of healthbased ventilation guidelines: principles and framework," International Journal of Environmental Research and Public Health, vol. 15, pp. 1360, 2018.

[13] N. Artmann, H. Manz and P. Heiselberg, "Climatic potential for passive cooling of buildings by night-time ventilation in Europe," Appl.Energy, vol. 84, pp. 187-201, 2007.

[14] P.M. Lynch and G.R. Hunt, "The night purging of a two-storey atrium building," Build.Environ., vol. 46, pp. 144-155, 2011.

[15] E. Solgi, Z. Hamedani, R. Fernando, H. Skates and N.E. Orji, "A literature review of night ventilation strategies in buildings," Energy Build., vol. 173, pp. 337-352, 2018.

[16] J. Le Dreau, P. Heiselberg and R.L. Jensen, "Experimental investigation of convective heat transfer during night cooling with different ventilation systems and surface emissivities," Energy Build., vol. 61, pp. 308-317, 2013.

[17] R. Guo, P. Heiselberg, Y. Hu, H. Johra, C. Zhang, R.L. Jensen, K.T. Jønsson and P. Peng, "Experimental investigation of heat transfer for night cooling with diffuse ceiling ventilation," Build.Environ., pp. 107665, 2021.

[18] M. Santamouris and D. Kolokotsa, "Passive cooling dissipation techniques for buildings and other structures: The state of the art," Energy Build., vol. 57, pp. 74-94, 2013.

[19] D.A. Coley and A. Beisteiner, "Carbon dioxide levels and ventilation rates in schools," International Journal of Ventilation, vol. 1, pp. 45-52, 2002.

[20] M. Griffiths and M. Eftekhari, "Control of CO2 in a naturally ventilated classroom," Energy Build., vol. 40, pp. 556-560, 2008.

[21] S.M. Almeida, N. Canha, A. Silva, M. do Carmo Freitas, P. Pegas, C. Alves, M. Evtyugina and C.A. Pio, "Children exposure to atmospheric particles in indoor of Lisbon primary schools," Atmos.Environ., vol. 45, pp. 7594-7599, 2011.

[22] C.Y.H. Chao and J.S. Hu, "Development of a dual-mode demand control ventilation strategy for indoor air quality control and energy saving," Build.Environ., vol. 39, pp. 385-397, 2004.

[23] J.F. Montgomery, S. Storey and K. Bartlett, "Comparison of the indoor air quality in an office operating with natural or mechanical ventilation using short-term intensive pollutant monitoring," Indoor and Built Environment, vol. 24, pp. 777-787, 2015.

[24] G.R. Hunt and N.B. Kaye, "Pollutant flushing with natural displacement ventilation," Build.Environ., vol. 41, pp. 1190-1197, 2006.

[25] J. Sundell, "On the history of indoor air quality and health," Indoor Air, vol. 14, pp. 51-58, 2004.

[26] S. Herberger, M. Herold, H. Ulmer, A. Burdack-Freitag, and F. Mayer, "Detection of human effluents by a MOS gas sensor in correlation to VOC quantification by GCMS," Building and Environment, 45(11), 2430-2439, 2010.

[27] M. Leidinger, T. Sauerwald, T. Conrad, W. Reimringer, G. Ventura, and A. Schütze, "Selective detection of hazardous indoor VOCs using metal oxide gas sensors," Procedia Engineering, 87, 1449-1452, 2014.

[28] A. Schütze, T. Baur, M. Leidinger, W. Reimringer, R. Jung, T. Conrad, and T. Sauerwald, "Highly sensitive and selective VOC sensor systems based on semiconductor 
gas sensors how to," Environments, 4(1), 20, 2017.

[29] C. Vornanen-Winqvist, H. Salonen, K. Järvi, M. A. Andersson, R. Mikkola, T. Marik, ... and J. Kurnitski, "Effects of ventilation improvement on measured and perceived indoor air quality in a school building with a hybrid ventilation system," International journal of environmental research and public health, 15(7), 1414, 2018.

[30] O. Toyinbo, R. Shaughnessy, M. Turunen, T. Putus, J. Metsämuuronen, J. Kurnitski, and U. Haverinen-Shaughnessy, "Building characteristics, indoor environmental quality, and mathematics achievement in Finnish elementary schools," Building and Environment, vol. 104, pp. 114-121, 2016.

[31] P. Carrer, P. Wargocki, A. Fanetti, W. Bischof, E.D.O. Fernandes, T. Hartmann, S.

Kephalopoulos, S. Palkonen and O. Seppänen, "What does the scientific literature tell us about the ventilation-health relationship in public and residential buildings?" Build.Environ., vol. 94, pp. 273-286, 2015.

[32] O. Seppänen, "Ventilation strategies for good indoor air quality and energy efficiency," International Journal of Ventilation, vol. 6, no. 4, pp. 297-306, 2008.

[33] G. Cao, H. Awbi, R. Yao, Y. Fan, K. Sirén, R. Kosonen and J.J. Zhang, "A review of the performance of different ventilation and airflow distribution systems in buildings," Build.Environ., vol. 73, pp. 171-186, 2014.

[34] A. K. Melikov, "Advanced air distribution: improving health and comfort while reducing energy use," Indoor air, vol. 26, no. 1, pp. 112-124, 2016.

[35] P. Wargocki and D.P. Wyon, "Providing better thermal and air quality conditions in school classrooms would be cost-effective,"

Build.Environ., vol. 59, pp. 581-589, 2013. 